\title{
Seasonal and size-dependent variations in the phytoplankton growth and microzooplankton grazing in the southern South China Sea under the influence of the East Asian monsoon
}

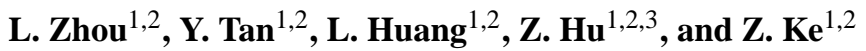 \\ ${ }^{1}$ CAS Key Laboratory of Tropical Marine Bio-resources and Ecology, South China Sea Institute of Oceanology, Chinese \\ Academy of Sciences, Guangzhou 510301, China \\ ${ }^{2}$ Guangdong Provincial Key Laboratory of Applied Marine Biology, Guangzhou 510301, China \\ ${ }^{3}$ University of Chinese Academy of Sciences, Beijing 100049, China
}

Correspondence to: Y. Tan (tanyh@ scsio.ac.cn)

Received: 23 March 2015 - Published in Biogeosciences Discuss.: 29 April 2015

Revised: 28 October 2015 - Accepted: 16 November 2015 - Published: 27 November 2015

\begin{abstract}
To examine seasonal and size-dependent variations in the phytoplankton growth and microzooplankton grazing in oligotrophic tropical waters under the influence of seasonal reversing monsoon, dilution experiments were conducted during the summer of 2009 (21 May to 9 June) and winter 2010 (9 to 18 November) in the southern South China Sea (SSCS). The results showed that environmental variables, phytoplankton biomass, phytoplankton growth rate $(\mu)$, microzooplankton grazing rate $(m)$, and correlationship (coupling) between the $\mu$ and $m$, rather than the microzooplankton grazing impact on phytoplankton $(m / \mu)$ significantly varied between the two seasons. Higher relative preference index (RPI) for the larger-sized $(>3 \mu \mathrm{m})$ phytoplankton than pico-phytoplankton $(<3 \mu \mathrm{m})$, indicating significant size-selective grazing by microzooplankton on the larger-sized phytoplankton, were also observed. The $\mu$ and $m$ were significantly correlated with seawater salinity and temperature, and phytoplankton biomass, which indicated that salient seasonal variations in the phytoplankton growth and microzooplankton grazing in the SSCS were closely related to the environmental variables under the influence of the East Asian monsoon. We propose that intermittent arrivals of the northeast winter monsoon could lead to the low $\mu$ and $m$, and the decoupling between the $\mu$ and $m$ in the SSCS, through influencing nutrient supply to the surface water, and inducing surface seawater salinity decrease. The low $m / \mu(<50 \%$ on average) indicates low remineralization of organic matter mediated by microzooplankton and mismatch between the $\mu$ and $m$, and thus probably accounts for part of the high
\end{abstract}

vertical biogenic particle fluxes in the prevailing periods of the monsoons in the SSCS. The size-selective grazing suggests that microzooplankton grazing partially contributes to the pico-phytoplankton dominance in the oligotrophic tropical waters such as that of the SSCS.

\section{Introduction}

Phytoplankton growth and microzooplankton grazing are crucial processes relating to ocean biogeochemistry and energy flow in the pelagic food web. Phytoplankton provides almost all of the primary production in the upper ocean. Microzooplankton $(<200 \mu \mathrm{m})$ consumes most of the daily primary production in the sea, and regulates phytoplankton community composition, and affects the ultimate fate of the phytoplankton-derived primary production (Banse, 2007, 2013; Landry and Calbet, 2004; Schmoker et al., 2013).

The dilution technique introduced by Landry and Hassett (1982) has extensively been used to estimate phytoplankton growth and synchronous microzooplankton grazing rates in varied marine ecosystems, although later modification and increasing use has also brought scrutiny and critiques (Dolanf and Mckeon, 2004; Gallegos, 1989; GutiérrezRodríguez et al., 2009; Teixeira and Figueiras, 2009). Based on global data collection, Schmoker et al. (2013) pointed out that seasonality of environmental variables and phytoplankton community induces seasonal variations in the phytoplankton growth and microzooplankton grazing in polar, sub- 
polar, and temperate regions, and tropical waters with salient seasonal reversing monsoon. However, there are few studies investigating both the phytoplankton growth and microzooplankton grazing in tropical oceans (Caron and Dennett, 1999; Chen et al., 2013; Landry et al., 1995, 1998, 2011), and the seasonality of phytoplankton growth and microzooplankton grazing in tropical waters influenced by salient seasonal reversing monsoon is still less known.

Microzooplankton may modify their food preference depending on the morphology, abundance and quality of prey, which would cause phytoplankton community shift in species and/or size composition (Teixeira and Figueiras, 2009). Phytoplankton community in oligotrophic subtropical and tropical waters is usually dominated by small-sized pico-cells $(<3 \mu \mathrm{m})$; the pico-phytoplankton consists of three major groups including Prochlorococcus, Synechoccus, and diverse types of pico-eukaryotic phytoplankton (Zubkov et al., 2000). Microzooplankton including both autotrophic and heterotrophic nanoflagellates can actively consume picosized prey (An-Yi et al., 2009; Christaki et al., 2005; FriasLopez et al., 2009). Landry et al. (1998) proposed that the balance between microzooplankton grazing and phytoplankton growth was consistent with the dominance of picoplankton in oligotrophic offshore regions in the Arabian Sea. Significantly higher microzooplankton grazing rates on the large-sized phytoplankton $(>5 \mu \mathrm{m})$ than the smaller one $(<5 \mu \mathrm{m})$ have been recently reported in the oligotrophic subtropical Northeast Atlantic (Cáceres et al., 2013). Our recent results suggest that size-selective grazing by microzooplankton on nano-sized $(3-20 \mu \mathrm{m})$ phytoplankton contributes to the pico-phytoplankton dominance in the oligotrophic tropical waters of the South China Sea (SCS) in summer (Zhou et al., 2015a). However, until now, the role played by microzooplankton in the pico-phytoplankton dominance in oligotrophic tropical waters is still less examined.

The southern SCS (SSCS) is characterized with permanent water stratification and oligotrophic conditions in the upper layer, and is affected by seasonal reversing monsoon. During the middle of May to September, the SSCS is under the influence of the southwest summer monsoon, while this area is influenced by the stronger northeast winter monsoon during November to the next April (Su, 2004). Seasonal variation of seawater salinity and temperature, vertical nutrient flux, and mixed-layer depth driven by the East Asian Monsoon have been reported (Fang et al., 2002; Liu et al., 2002; Longhurst, 2007; Ning et al., 2004). Mesoscale eddies with obvious seasonal variation (Fang et al., 1998, 2002; Zhang et al., 2014) and seasonal pattern of higher phytoplankton biomass, primary production, and vertical biogenic particle fluxes during the prevailing periods of the monsoons and wintertime occur in the SSCS (Liu et al., 2002; Ning et al., 2004; Wan et al., 2010). There are hundreds of coral shoals, reefs, and islands called the Nansha Islands located in this area, making the SSCS worthy of a component of the Archipelagic Deep Basins Province (ARCH) defined by
Longhurst (2007) . Many researchers including Qingchao Chen, Liangmin Huang and their co-workers from the South China Sea Institute of Oceanology, Chinese Academy of Sciences, have previously investigated the environment variables, marine species diversity, and ecological processes in the coral reef lagoons of the Nansha Islands and its adjacent waters during the 1980s to 1990s (e.g. Chen and Mutidisciplinary Expedition to Nansha Islands, 1991, 1989, 1994, 1996, 1998; Huang and Multidisciplinary Expedition to Nansha Islands, 1997). Their works provide valuable contributions to the understanding of the taxonomic composition and distribution of phytoplankton, bacteria, zooplankton and fish, and ecological processes such as primary production in the SSCS. However, these results are seldom published in international media, even in scientific journals in Chinese, and are thus less known to the scientific community. So far, there are no data reported on the microzooplankton grazing in this region. We hypothesize that seasonal changes in both the phytoplankton growth and microzooplankton grazing is expected in the tropical waters influenced by salient seasonal reversing monsoon, and microzooplankton contributes to the phytoplankton size composition through size-selective grazing in the SSCS.

To test the hypotheses, we conducted a series of dilution experiments in adjacent waters of the Nansha Islands in the SSCS during two cruises in May to June 2009 and November 2010. Significant seasonal variations in the phytoplankton growth and microzooplankton grazing and apparently size-selective grazing were observed.

\section{Material and methods}

Dilution experiments (Landry and Hassett, 1982) were conducted at 14 stations during 21 May to 9 June 2009 (summer), and at 10 stations during 9 November to 18 November 2010 (winter). Stations KJ28 and KJ32 were located at the basin waters northwest to the Nansha Islands; station YS was located at the lagoon of the Yongshu Reef/Island, the other stations were distributed in waters around the Nansha Islands (Fig. 1).

Surface seawater was collected and pre-screened with a 200- $\mu \mathrm{m}$ nylon netting for dilution experiments at each station. Particle-free seawater was obtained by filtering the seawater through a filter with a pore size of $0.22 \mu \mathrm{m}$. All the bottles, containers, and filters were soaked in $10 \% \mathrm{HCl}$ for more than $10 \mathrm{~h}$, and thoroughly washed with deionized water and MiliQ-water before each cruise. The bottles and containers were washed with $10 \% \mathrm{HCl}$, deionized water and ambient seawater before each experiment. Measured amount of particle-free seawater was firstly added to the $2.4 \mathrm{~L}$ polycarbonate bottles, and unfiltered seawater was added and filled the bottles. Four dilution treatments of 25, 50, 75, and $100 \%$ unfiltered seawater were prepared for the summer experiments, and another four dilution treatments of 37.5, 58.3, 


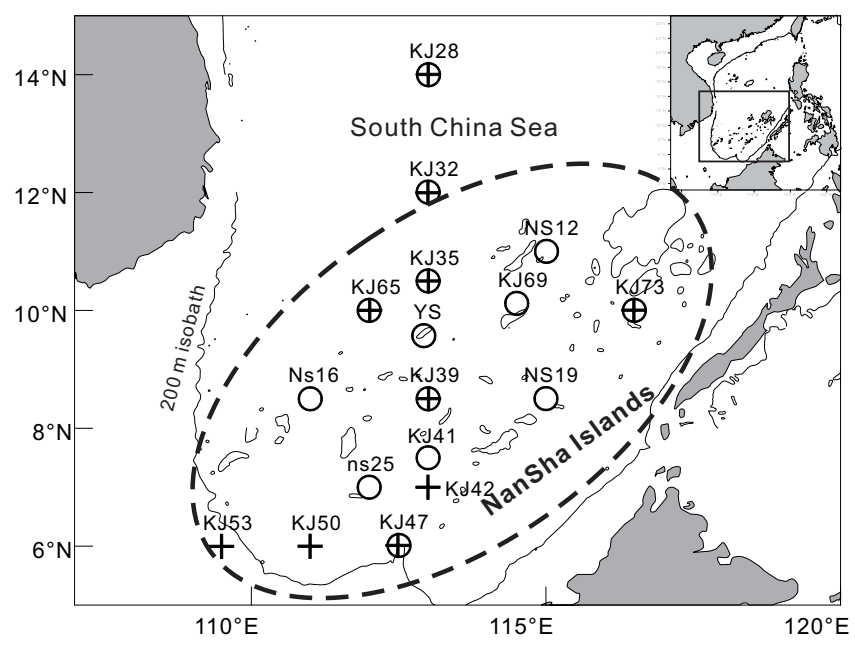

Figure 1. Stations for dilution experiments in the southern South China Sea during May to June 2009 and November 2010. The open circle indicates experimental stations during May to June 2009; the cross indicates experimental stations during November 2010. The dashed circle shows the schematic area of the Nansha Islands.

79.2, and $100 \%$ unfiltered seawater were prepared for the winter experiments. All the bottles were enriched with additional nutrients (final concentrations of $0.5 \mu \mathrm{M} \mathrm{NH} \mathrm{N}_{4} \mathrm{Cl}$, $0.03 \mu \mathrm{M} \mathrm{KH}_{2} \mathrm{PO}_{4}, 1.0 \mathrm{nM} \mathrm{FeSO}_{4}$ and $0.1 \mathrm{nM} \mathrm{MnCl}_{2}$ ) to promote constant phytoplankton growth. Two bottles were filled with unfiltered seawater without nutrient enrichment served as no nutrient controls. Another two bottles filled with unfiltered seawater were sacrificed for initial samples of chlorophyll $a(\mathrm{Chl} a)$. All of the bottles were incubated for $24 \mathrm{~h}$ in a deck incubator cooled by running surface seawater and covered with neutral-density screens to simulate in situ light regime. These measures have been proved effective to avoid phytoplankton photoacclimation during the incubation (Zhou et al., 2015a)

Seawater was filtered through a sequence of 3- $\mu \mathrm{m}$ pore size polycarbonate filter and GF/F filter for size-fractionated Chl $a$ of the larger-sized ( $>3 \mu \mathrm{m})$ and pico- $(<3 \mu \mathrm{m})$ phytoplankton. Total Chl $a$ was calculated as the sum of the two size fractions or directly sampled by filtering 0.5 to $1 \mathrm{~L}$ seawater on the GF/F filter. The filters were extracted in $90 \%$ acetone at $-20^{\circ} \mathrm{C}$ for $24 \mathrm{~h}$. The $\mathrm{Chl} a$ concentration was measured by fluorometry using a Turner Designs Model 10 Fluorometer (Parsons et al., 1984).

Seawater temperature, salinity, and silicate concentration were also measured. Temperature and salinity were determined by Conductivity-Temperature-Depth probes. Silicate in seawater was analysed with a flow-injection autoanalyser (Quickchem 8500, Lachat Instruments) following the standard manuals.

Assuming an exponential growth model, the net growth rate $\left(k_{d}\right)$ of phytoplankton in a dilution treatment was calculated according to the formula $k_{d}=\ln \left(P_{t} / d \mathrm{P}_{0}\right)$, where $d$ is the dilution factor (the proportion of unfiltered seawater), $P_{t}$ is the Chl $a$ concentration after incubation and $P_{0}$ is the initial Chl $a$ concentration. Phytoplankton growth rates with nutrient amendment $\left(\mu_{\mathrm{n}}\right)$ and microzooplankton grazing rates $(m)$ were estimated from Model I linear regressions of net growth rate $(k)$ vs. dilution factor $(d)$. In situ phytoplankton instantaneous growth rates $(\mu)$ were calculated as the sum of $m$ and net growth rate in control bottles without added nutrients.

When saturated or saturated-increasing grazing was observed as a departure from the assumed linear model (Gallegos, 1989; Teixeira and Figueiras, 2009) by visual inspection of the plots, $m$ and $\mu$ were calculated on the basis of the method of Chen et al. (2009a).

Size-fractionated ( $>3$ and $<3 \mu \mathrm{m}$ ) phytoplankton growth and mortality rates were estimated for experiments at YS and KJ35 during the summer cruise, and all the experiments during the winter cruise.

Nutrient limitation index indicating nutrient sufficiency for phytoplankton growth was assessed by the ratio $\mu / \mu_{\mathrm{n}}$, which is expected to vary with system trophic state (Landry et al., 1998). The microzooplankton grazing impact on phytoplankton was assessed by the ratio of microzooplankton grazing to phytoplankton growth rates $(m / \mu)$, and measures the extent to which the daily phytoplankton production is consumed and balanced by microzooplankton grazing (Landry et al., 1998).

Grazing selectivity for size-fractionated phytoplankton was analysed following the relative preference index (RPI) provided by Obayashi and Tanoue (2002) as $\mathrm{RPI}=\frac{\left[m \operatorname{chl} a_{i}\right] / \sum\left[m \mathrm{chl} a_{i}\right]}{\left[\operatorname{chl} a_{i}\right] / \sum\left[\mathrm{chl} a_{i}\right]}$, where $[\mathrm{mchl} a]$ is the amount of daily grazed Chl $a\left(\mu \mathrm{g} \mathrm{L}^{-1} \mathrm{~d}^{-1}\right)$, subscript $i$ refers to each size fraction analysed and [Chl $a]$ is the concentration of $\mathrm{Chl} a\left(\mu \mathrm{g} \mathrm{L}{ }^{-1}\right)$. RPI $>1$ indicates positive selection and vice versa.

All the statistical analyses were conducted by using the SPSS 17.0. The average value of the ratio variables such as $\mathrm{m} / \mu$ was presented as the geometric mean, while other average values were presented as the arithmetic mean.

\section{Results}

\subsection{Environmental variables and $\operatorname{Chl} a$}

Environmental variables and Chl $a$ in surface seawater were different between the two cruises (Tables 1 and 2). Surface seawater temperature (SST) and salinity (SSS) were significantly lower (independent $t$ test, $p<0.05$ or 0.01 ), while the concentration of silicate was significantly higher in the winter cruise (independent $t$ test, $p<0.05$ ) than that in the summer cruise. Vertical profiles of these variables also demonstrated the significant seasonal variations (Fig. 2). The concentration of Chl $a$ in the winter cruise (mean $\pm \mathrm{sd}$ : $0.104 \pm 0.024 \mu \mathrm{g} \mathrm{L}^{-1}$ ) was about 2 times that in the sum- 

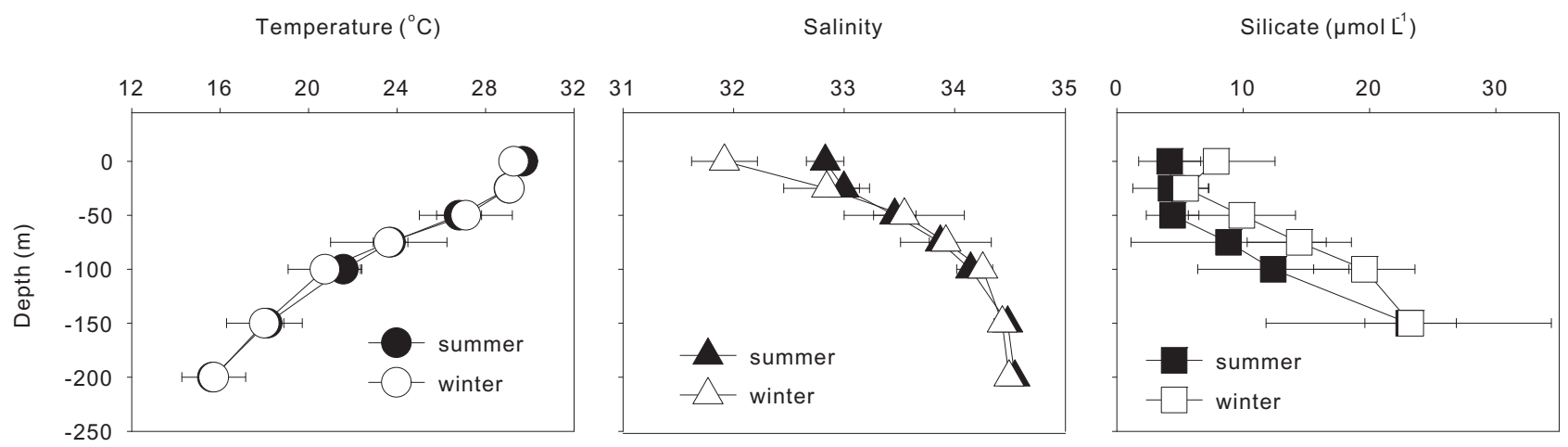

Figure 2. Vertical profiles of seawater temperature, salinity, and silicate concentration in the southern South China Sea during May to June 2009 (summer) and November 2010 (winter). The error bar indicates standard deviation.

mer cruise (mean $\pm \mathrm{sd}$ : $0.066 \pm 0.022 \mu \mathrm{g} \mathrm{L} \mathrm{L}^{-1}$ ) (independent $t$ test, $p<0.01)$. Pico-phytoplankton $(<3 \mu \mathrm{m})$ accounted for most $(>80 \%)$ of the total Chl $a$ during both the cruises. The proportion of pico-phytoplankton in the winter cruise (mean \pm sd: $81.9 \pm 5.0 \%$ ) was similar to that in the summer cruise (mean \pm sd: $83.0 \pm 1.8 \%$ ) (independent $t$ test, $p>0.1)$.

\subsection{Feeding responses in dilution experiments}

The detailed results of each dilution experiment were listed in Tables 1 and 2. Except for linear feeding responses, both the saturated and saturated-increased feeding responses described by Teixeira and Figueiras (2009) occurred in the dilution experiments during both the cruises (Fig. 3a-c). Nonlinear feeding responses occurred at 8 of the 14 experiments during the summer cruise, while those occurred at 4 of the 10 experiments during the winter cruise (Tables 1 and 2). During the winter cruise, substantially negative phytoplankton growth rates $(\mu)$ and high microzooplankton grazing rates ( $m$ ) were observed at KJ53 (Fig. 3d-f). The negative $\mu$ obtained at KJ53 and the derivative parameters (e.g. $m / \mu$ ) were not included for the comparison between seasons and size fractions.

\subsection{Comparison of the phytoplankton growth and microzooplankton grazing between the two seasons}

The phytoplankton growth and microzooplankton grazing were significantly different between the two cruises. The $\mu$ in the winter cruise (mean \pm sd: $0.54 \pm 0.22 \mathrm{~d}^{-1}$ ) was significantly lower than those in the summer cruise (mean $\pm \mathrm{sd}$ : $0.92 \pm 0.32 \mathrm{~d}^{-1}$ ) (independent $t$ test, $p<0.01$ ). The $m$ in the winter cruise (mean \pm sd: $0.27 \pm 0.13 \mathrm{~d}^{-1}$ ) was also significantly lower than those in the summer cruise (mean $\pm \mathrm{sd}$ : $0.46 \pm 0.20 \mathrm{~d}^{-1}$ ) (independent $t$ test, $p<0.01$ ). However, the $m / \mu$ ratio was almost equally low both in the summer (geometric mean \pm sd: $49 \pm 23 \%$ ) and winter (geometric mean \pm sd: $48 \pm 33 \%$ ) cruises.

\subsection{Size-dependent phytoplankton growth and microzooplankton grazing}

The $\mu$ and $m$ varied between size fractions. Higher $m$ on the larger size fraction was observed at YS $\left(0.65 \mathrm{~d}^{-1}\right.$ for the size fraction $>3 \mu \mathrm{m}$ vs. $0.33 \mathrm{~d}^{-1}$ for the size fraction $\left.<3 \mu \mathrm{m}\right)$ and KJ35 $\left(0.39 \mathrm{~d}^{-1}\right.$ for the size fraction $>3 \mu \mathrm{m}$ vs. $0.30 \mathrm{~d}^{-1}$ for the size fraction $<3 \mu \mathrm{m}$ ) during the summer cruise. The $\mu$ of the larger-sized $(>3 \mu \mathrm{m})$ and pico- $(<3 \mu \mathrm{m})$ phytoplankton were 1.07 and $0.75 \mathrm{~d}^{-1}$ at $\mathrm{YS}$, and 0.69 and $0.90 \mathrm{~d}^{-1}$ at $\mathrm{KJ} 35$, respectively. During the winter cruise, the $m$ on the larger size fraction (mean $\pm \mathrm{sd}: 0.50 \pm 0.41 \mathrm{~d}^{-1}$ ) was higher than those on pico-phytoplankton (mean \pm sd: $0.27 \pm 0.27 \mathrm{~d}^{-1}$ ) at 7 of the 10 experiments, and the $\mu$ of the larger size fraction (mean \pm sd: $0.88 \pm 0.38 \mathrm{~d}^{-1}$ ) were also higher than those of pico-phytoplankton (mean $\pm \mathrm{sd}: 0.42 \pm 0.31 \mathrm{~d}^{-1}$ ) at 7 of the 9 experiments (exclude data at KJ53) (Table 3). The $m / \mu$ was higher for the larger size fraction $(57.3 \%$ at KJ35 and $61.2 \%$ at YS) than pico-phytoplankton (33.3\% at $\mathrm{KJ} 35$ and $44.0 \%$ at YS) during the summer cruise, while the $m / \mu$ was not significantly different between the two size fractions $(41.1 \pm 82.8 \%$ for the size fraction $>3 \mu \mathrm{m}$, and $39.4 \pm 21.1 \%$ for the size fraction $<3 \mu \mathrm{m})$ during the winter cruise (Table 3 ).

Higher RPI for the larger-sized phytoplankton than picophytoplankton was observed during both cruises (Fig. 4). The RPI for the larger-sized phytoplankton was higher than one (geomean $\pm \mathrm{sd}: 1.44 \pm 0.31$ ), while the RPI for pico-phytoplankton was lower than one (geomean $\pm \mathrm{sd}$ : $0.90 \pm 0.07)$ during the summer cruise. The RPI was significantly (Mann-Whitney test, $p<0.05$ ) higher for the largersized phytoplankton (geomean \pm sd: $1.44 \pm 1.57$ ) than picophytoplankton (geomean \pm sd: $0.61 \pm 0.35$ ) during the winter cruise.

\subsection{Nutrient limitation to the phytoplankton growth}

Nutrient limitation index $\left(\mu / \mu_{\mathrm{n}}\right)$ was significantly higher (Mann-Whitney test, $p<0.05$ ) during the summer cruise 
Table 1. Summary of environmental variables, phytoplankton growth rates with $\left(\mu_{\mathrm{n}}, \mathrm{d}^{-1}\right)$ and $\left(\mu, \mathrm{d}^{-1}\right)$ without nutrient amendment, and microzooplankton grazing rates $\left(m, \mathrm{~d}^{-1}\right)$ in the southern South China Sea in May-June 2009. SST, surface seawater temperature $\left({ }^{\circ} \mathrm{C}\right)$; SSS, surface seawater salinity; 25-T $(S)$ seawater temperature (salinity) at $25 \mathrm{~m}$ in depth; Si, silicate ( $\mu$ mol L ${ }^{-1}$ ); Chl $a$, chlorophyll $a$ ( $\mu \mathrm{g} \mathrm{L}{ }^{-1}$ ); $n$, the number of data points in the linear part; $R^{2}$, the determination coefficient of the regression of the linear part; se, standard error; the superscript "a" denotes a saturated feeding response; the superscript " $b$ " denotes a saturated-increased feeding response. The significant level $(p)$ of regressions when saturated or saturated-increased feeding responses occurred was in some occasions $>0.05$ owing to the few points included in the regression.

\begin{tabular}{|c|c|c|c|c|c|c|c|c|c|c|c|c|c|c|c|c|}
\hline Station & Date & Depth & SST & SSS & $25-T$ & $25-S$ & $\mathrm{Si}$ & Chl $a$ & $\mu_{\mathrm{n}}$ & $m \pm \mathrm{se}$ & $\mu \pm \mathrm{se}$ & $R^{2}$ & $n$ & $p$ & $\mu / \mu_{\mathrm{n}}$ & $m / \mu \pm \mathrm{se}$ \\
\hline $\mathrm{KJ} 28$ & 21 May & 2899 & 29.90 & 32.90 & 28.02 & 33.07 & 2.0 & 0.087 & 1.01 & $0.34 \pm 0.06$ & $1.09 \pm 0.03$ & 0.88 & $6^{\mathrm{a}}$ & 0.006 & 1.08 & $0.31 \pm 0.02$ \\
\hline KJ35 & 22 May & 3243 & 29.60 & 32.41 & 29.05 & 32.91 & 1.6 & 0.086 & 1.11 & $0.30 \pm 0.19$ & $0.85 \pm 0.08$ & 0.83 & $4^{\mathrm{a}}$ & 0.086 & 0.77 & $0.35 \pm 0.11$ \\
\hline YS & 23 May & 28 & 29.10 & 32.77 & - & - & 0.3 & 0.082 & 0.74 & $0.40 \pm 0.17$ & $0.82 \pm 0.11$ & 0.50 & 8 & 0.052 & 1.12 & $0.49 \pm 0.08$ \\
\hline KJ41 & 25 May & 1724 & 29.93 & 32.83 & 28.60 & 33.25 & 1.7 & 0.079 & 1.04 & $0.57 \pm 0.13$ & $0.84 \pm 0.09$ & 0.76 & 8 & 0.005 & 0.80 & $0.68 \pm 0.06$ \\
\hline KJ47 & 26 May & 468 & 31.03 & 32.60 & 29.63 & 32.90 & 1.8 & 0.049 & 1.10 & $0.61 \pm 0.12$ & $0.90 \pm 0.06$ & 0.87 & $6^{\mathrm{b}}$ & 0.007 & 0.82 & $0.67 \pm 0.06$ \\
\hline NS25 & 28 May & 2025 & 30.12 & 32.72 & 29.65 & 32.74 & 6.8 & 0.036 & 1.16 & $0.71 \pm 0.21$ & $1.30 \pm 0.14$ & 0.66 & 8 & 0.015 & 1.12 & $0.55 \pm 0.06$ \\
\hline NS19 & 30 May & 2057 & 30.28 & 32.94 & 29.18 & 33.20 & 1.0 & 0.050 & 1.51 & $0.79 \pm 0.45$ & $1.20 \pm 0.28$ & 0.61 & $4^{b}$ & 0.216 & 0.79 & $0.66 \pm 0.20$ \\
\hline KJ39 & 31 May & 2001 & 29.60 & 32.89 & 29.11 & 33.03 & 9.0 & 0.050 & 1.50 & $0.49 \pm 0.09$ & $0.83 \pm 0.06$ & 0.85 & 8 & 0.001 & 0.55 & $0.59 \pm 0.04$ \\
\hline NS16 & 31 May & 1589 & 29.88 & 32.94 & 29.77 & 33.01 & 5.2 & 0.044 & 1.00 & $0.46 \pm 0.17$ & $1.04 \pm 0.11$ & 0.56 & 8 & 0.033 & 1.05 & $0.44 \pm 0.06$ \\
\hline KJ65 & 02 Jun & 2999 & 28.95 & 32.82 & 28.78 & 32.90 & 3.4 & 0.096 & 0.64 & $0.21 \pm 0.09$ & $0.19 \pm 0.05$ & 0.90 & $6^{\mathrm{b}}$ & 0.004 & 0.29 & $1.13 \pm 0.22$ \\
\hline KJ69 & 05 Jun & 1522 & 29.02 & 32.86 & 28.93 & 32.93 & 6.5 & 0.057 & 2.30 & $0.66 \pm 0.03$ & $1.50 \pm 0.02$ & 0.99 & 8 & $<0.001$ & 0.65 & $0.44 \pm 0.01$ \\
\hline KJ73 & 06 Jun & 1785 & 29.50 & 32.84 & 29.24 & 32.90 & 6.4 & 0.045 & 0.78 & $0.48 \pm 0.52$ & $0.87 \pm 0.20$ & 0.30 & $4^{b}$ & 0.450 & 1.11 & $0.55 \pm 0.30$ \\
\hline NS12 & 07 Jun & 920 & 29.26 & 33.05 & 28.90 & 33.12 & 4.6 & 0.062 & 1.19 & $0.39 \pm 0.09$ & $0.88 \pm 0.05$ & 0.82 & $6^{\mathrm{b}}$ & 0.013 & 0.73 & $0.45 \pm 0.05$ \\
\hline KJ32 & 09 Jun & 4229 & 28.84 & 32.97 & 28.85 & 33.00 & 3.2 & 0.105 & 0.54 & $0.09 \pm 0.02$ & $0.54 \pm 0.01$ & 0.99 & $4^{a}$ & 0.006 & 0.99 & $0.16 \pm 0.02$ \\
\hline
\end{tabular}

Table 2. Summary of environmental variables, phytoplankton growth rates with $\left(\mu_{\mathrm{n}}, \mathrm{d}^{-1}\right)$ and without $\left(\mu, \mathrm{d}^{-1}\right)$ nutrient amendment, and microzooplankton grazing rates $\left(m, \mathrm{~d}^{-1}\right)$ in the southern South China Sea in November 2010. SST, surface seawater temperature $\left({ }^{\circ} \mathrm{C}\right)$; SSS, surface seawater salinity; 25-T $(S)$ seawater temperature (salinity) at $25 \mathrm{~m}$ in depth; $\mathrm{Si}$, silicate $\left(\mu \mathrm{mol} \mathrm{L}{ }^{-1}\right)$; $\mathrm{Chl}_{a}$, chlorophyll $a\left(\mu \mathrm{g} \mathrm{L}{ }^{-1}\right.$ ); $n$, the number of data points in the linear part; $R^{2}$, the determination coefficient of the regression of the linear part; se, standard error; the superscript "a" denotes a saturated feeding response; the superscript " $b$ " denotes a saturated-increased feeding response. The significant level $(p)$ of regressions when saturated-increased feeding responses occurred was in some occasions $>0.05$ owing to the few points included in the regression.

\begin{tabular}{|c|c|c|c|c|c|c|c|c|c|c|c|c|c|c|c|c|c|}
\hline Station & Date & Depth & SST & SSS & $25-T$ & $25-S$ & $\mathrm{Si}$ & $>3 \mu \mathrm{m} \mathrm{Chl} a$ & $<3 \mu \mathrm{m} \mathrm{Chl} a$ & $\mu_{\mathrm{n}}$ & $m \pm \mathrm{se}$ & $\mu \pm \mathrm{se}$ & $R^{2}$ & $n$ & $p$ & $\mu / \mu_{\mathrm{n}}$ & $m / \mu \pm \mathrm{se}$ \\
\hline KJ28 & $09 \mathrm{Nov}$ & 2538 & 28.89 & 32.35 & 28.74 & 33.33 & 8.4 & 0.013 & 0.120 & 0.66 & $0.17 \pm 0.04$ & $0.45 \pm 0.03$ & 0.77 & 8 & 0.009 & 0.69 & $0.38 \pm 0.03$ \\
\hline KJ32 & 09 Nov & 4229 & 29.07 & 32.20 & 28.93 & 33.50 & 6.5 & 0.024 & 0.085 & 1.30 & $0.16 \pm 0.09$ & $0.74 \pm 0.06$ & 0.37 & 8 & 0.108 & 0.57 & $0.22 \pm 0.04$ \\
\hline KJ35 & $10 \mathrm{Nov}$ & 2903 & 28.97 & 31.86 & 28.05 & 32.15 & 5.9 & 0.013 & 0.084 & 1.28 & $0.43 \pm 0.15$ & $0.96 \pm 0.12$ & 0.67 & 6 & 0.047 & 0.75 & $0.45 \pm 0.07$ \\
\hline KJ39 & $11 \mathrm{Nov}$ & 1996 & 29.22 & 31.70 & 29.41 & 33.11 & 20.2 & 0.015 & 0.091 & 0.77 & $0.26 \pm 0.20$ & $0.28 \pm 0.10$ & 0.89 & $4^{b}$ & 0.059 & 0.37 & $0.92 \pm 0.39$ \\
\hline KJ42 & $12 \mathrm{Nov}$ & 1460 & 29.62 & 31.46 & 29.32 & 32.66 & 7.3 & 0.017 & 0.088 & 0.39 & $0.13 \pm 0.11$ & $0.50 \pm 0.06$ & 0.38 & $4^{\mathrm{b}}$ & 0.383 & 1.27 & $0.25 \pm 0.11$ \\
\hline KJ47 & $13 \mathrm{Nov}$ & 511 & 29.45 & 32.31 & 29.33 & 32.36 & 9.7 & 0.037 & 0.121 & 1.84 & $0.46 \pm 0.62$ & $0.60 \pm 0.50$ & 0.12 & 6 & 0.497 & 0.33 & $0.77 \pm 0.50$ \\
\hline KJ50 & $14 \mathrm{Nov}$ & 1259 & 29.22 & 31.69 & 29.18 & 32.98 & 6.0 & 0.020 & 0.069 & 0.90 & $0.13 \pm 0.08$ & $0.43 \pm 0.04$ & 0.94 & $4^{b}$ & 0.030 & 0.48 & $0.30 \pm 0.09$ \\
\hline KJ53 & $14 \mathrm{Nov}$ & 145 & 29.62 & 32.06 & 28.92 & 33.20 & 3.8 & 0.017 & 0.050 & -2.03 & $1.01 \pm 0.33$ & $-2.06 \pm 0.24$ & 0.65 & 8 & 0.015 & - & - \\
\hline KJ65 & $16 \mathrm{Nov}$ & 2100 & 29.26 & 31.83 & 29.27 & 32.93 & 6.6 & 0.014 & 0.077 & 0.97 & $0.33 \pm 0.16$ & $0.28 \pm 0.13$ & 0.52 & 6 & 0.106 & 0.29 & $1.15 \pm 0.31$ \\
\hline KJ73 & $18 \mathrm{Nov}$ & 1672 & 29.42 & 31.72 & 29.50 & 32.84 & 4.4 & 0.017 & 0.077 & 0.87 & $0.34 \pm 0.10$ & $0.57 \pm 0.05$ & 0.94 & $4^{a}$ & 0.030 & 0.66 & $0.59 \pm 0.09$ \\
\hline
\end{tabular}

(geometric mean \pm sd: $0.80 \pm 0.25$ ) than the winter cruise (geometric mean \pm sd: $0.54 \pm 0.30$ ). The $\mu / \mu_{\mathrm{n}}$ was approximate to or larger than 1 at 5 of the 14 experiments in the summer. In contrast, the $\mu / \mu_{\mathrm{n}}$ was apparently lower than one at 8 of the 9 experiments (excluding data at KJ53) in the winter (Tables 1 and 2).

\subsection{Correlations between the growth and grazing rates with environmental variables}

Taking all the data from the two cruises together, the average $\mu$ and $m$ were $0.77 \pm 0.34$ and $0.39 \pm 0.20 \mathrm{~d}^{-1}$. The $\mu$ were positively correlated with SST $(r=0.43, p<0.05)$, SSS $(r=0.55, p<0.01), \mu / \mu_{\mathrm{n}}(r=0.50, p<0.05)$, net phytoplankton growth rate $(r=0.83, p<0.01)$, and $m(r=$ $0.76, p<0.01)$, but were negatively correlated with $\mathrm{Chl} a$ $(r=-0.65, p<0.01$ ) (Table 4$)$. The $m$ were also positively correlated with SST $(r=0.62, p<0.01)$ and SSS $(r=0.48$, $p<0.05)$, but was negatively correlated with Chl $a(r=$ $-0.66, p<0.01$ ) (Table 4)

\subsection{Correlations between the phytoplankton growth and microzooplankton grazing}

The positive correlation $\left(r^{2}=0.57, p<0.01\right)$ between $\mu$ and $m$ was observed during the summer cruise (Fig. 5a). However, there was no significant correlation between the total $\mu$ and $m$ during the winter cruise $\left(r^{2}=0.12, p>0.1\right)$. By grouping $\mu$ and $m$ separately for each size fraction, it is found that the correlation was significant for the larger size fraction $\left(r^{2}=0.84, p<0.05\right)$ but not for the pico-phytoplankton $\left(r^{2}=0.41, p=0.07\right)$ (Fig. 5b). 

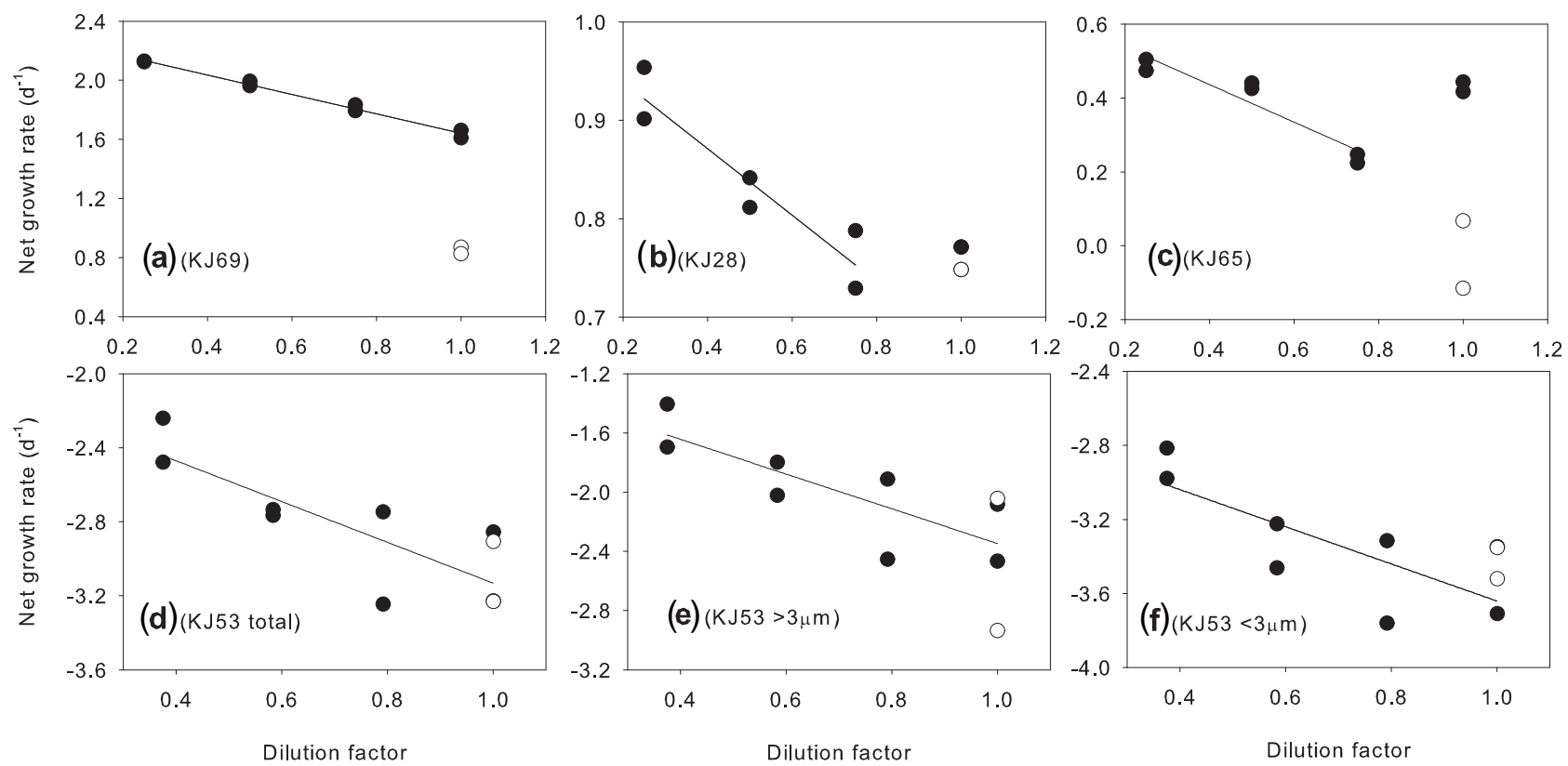

Figure 3. Examples of dilution experiment plots of net phytoplankton growth rate as a function of dilution factor. (a) Linear feeding responses in the dilution experiment at KJ69; (b) saturated feeding responses in the dilution experiment at KJ28; (c) saturated-increasing feeding responses in the dilution experiment at KJ65; (d-f) negative phytoplankton growth rates at KJ53, (d) for total phytoplankton, (e) for the size fraction $>3 \mu \mathrm{m}$ and (f) for the size fraction $<3 \mu \mathrm{m}$; the black circle indicates experimental bottles enriched with addition nutrients; the open circle indicates experimental bottles without nutrient amendment.

Table 3. Comparison of phytoplankton growth and mortality rates between two size fractions in the southern South China Sea in November 2010. $\mu_{\mathrm{n}}$, phytoplankton growth rates with nutrient amendment $\left(\mathrm{d}^{-1}\right) ; \mu$, phytoplankton growth rates without nutrient amendment $\left(\mathrm{d}^{-1}\right)$; $m$, microzooplankton grazing rates or phytoplankton mortality rates caused by microzooplankton grazing $\left(\mathrm{d}^{-1}\right)$; se, standard error; the superscript "a" denotes a saturated feeding response; the superscript " $b$ " denotes a saturated-increased feeding response. The significant level $(p)$ of regressions when saturated or saturated-increased feeding responses occurred was in some occasions $>0.05$ owing to the few points included in the regression.

\begin{tabular}{|c|c|c|c|c|c|c|c|c|c|}
\hline Size fraction & Station & $\mu_{\mathrm{n}}$ & $m \pm \mathrm{se}$ & $\mu \pm \mathrm{se}$ & $R^{2}$ & $n$ & $p$ & $\mu / \mu_{\mathrm{n}}$ & $m / \mu$ \\
\hline \multirow[t]{10}{*}{$<3 \mu \mathrm{m}$} & $\mathrm{KJ} 28$ & 0.57 & $0.15 \pm 0.06$ & $0.39 \pm 0.04$ & 0.57 & 8 & 0.050 & 0.69 & $0.37 \pm 0.05$ \\
\hline & KJ32 & 1.29 & $0.16 \pm 0.12$ & $0.78 \pm 0.09$ & 0.23 & 8 & 0.231 & 0.60 & $0.21 \pm 0.06$ \\
\hline & KJ35 & 1.30 & $0.50 \pm 0.18$ & $1.01 \pm 0.15$ & 0.65 & 6 & 0.052 & 0.78 & $0.50 \pm 0.08$ \\
\hline & KJ39 & 0.50 & $0.12 \pm 0.15$ & $0.05 \pm 0.07$ & 0.89 & $4^{\mathrm{a}}$ & 0.058 & 0.10 & $2.42 \pm 2.34$ \\
\hline & $\mathrm{KJ} 42$ & 0.26 & $0.05 \pm 0.18$ & $0.33 \pm 0.09$ & 0.04 & $4^{b}$ & 0.791 & 1.24 & $0.16 \pm 0.29$ \\
\hline & KJ47 & 1.27 & $0.10 \pm 1.67$ & $0.18 \pm 1.16$ & 0.00 & $4^{\mathrm{a}}$ & 0.958 & 0.14 & $0.55 \pm 4.92$ \\
\hline & KJ50 & 0.73 & $0.01 \pm 0.05$ & $0.32 \pm 0.02$ & 0.96 & $4^{b}$ & 0.020 & 0.43 & $0.03 \pm 0.07$ \\
\hline & KJ53 & -2.64 & $0.89 \pm 0.34$ & $-2.55 \pm 0.25$ & 0.59 & 8 & 0.027 & 0.96 & - \\
\hline & KJ65 & 0.85 & $0.29 \pm 0.17$ & $0.15 \pm 0.14$ & 0.42 & 6 & 0.167 & 0.18 & $1.88 \pm 0.83$ \\
\hline & KJ73 & 0.80 & $0.39 \pm 0.05$ & $0.58 \pm 0.03$ & 0.94 & $6^{\mathrm{a}}$ & 0.001 & 0.73 & $0.67 \pm 0.04$ \\
\hline \multirow[t]{10}{*}{$>3 \mu \mathrm{m}$} & $\mathrm{KJ} 28$ & 1.20 & $0.22 \pm 0.07$ & $0.77 \pm 0.05$ & 0.68 & 8 & 0.012 & 0.64 & $0.29 \pm 0.03$ \\
\hline & KJ32 & 1.34 & $0.17 \pm 0.05$ & $0.62 \pm 0.04$ & 0.65 & 8 & 0.015 & 0.46 & $0.28 \pm 0.03$ \\
\hline & KJ35 & 1.14 & $0.09 \pm 0.06$ & $0.62 \pm 0.04$ & 0.26 & 8 & 0.192 & 0.54 & $0.14 \pm 0.03$ \\
\hline & KJ39 & 1.71 & $1.31 \pm 0.38$ & $1.76 \pm 0.19$ & 0.86 & $4^{b}$ & 0.075 & 1.03 & $0.75 \pm 0.12$ \\
\hline & $\mathrm{KJ} 42$ & 0.89 & $0.38 \pm 0.49$ & $1.14 \pm 0.24$ & 0.23 & $4^{\mathrm{b}}$ & 0.520 & 1.28 & $0.34 \pm 0.22$ \\
\hline & KJ47 & 2.32 & $0.45 \pm 0.46$ & $0.69 \pm 0.33$ & 0.14 & 8 & 0.365 & 0.30 & $0.65 \pm 0.26$ \\
\hline & KJ50 & 1.34 & $0.68 \pm 0.15$ & $0.97 \pm 0.07$ & 0.91 & $4^{\mathrm{a}}$ & 0.046 & 0.72 & $0.70 \pm 0.08$ \\
\hline & KJ53 & -1.17 & $1.10 \pm 0.35$ & $-1.39 \pm 0.26$ & 0.65 & 8 & 0.016 & 1.18 & - \\
\hline & KJ65 & 1.23 & $0.22 \pm 0.21$ & $0.56 \pm 0.15$ & 0.16 & 8 & 0.328 & 0.46 & $0.40 \pm 0.14$ \\
\hline & $\mathrm{KJ} 73$ & 1.03 & $0.35 \pm 0.18$ & $0.77 \pm 0.09$ & 0.92 & $4^{b}$ & 0.041 & 0.75 & $0.46 \pm 0.12$ \\
\hline
\end{tabular}


Table 4. Pearson correlation analyses between dilution experimental parameters and environmental variables. $\mu$, phytoplankton growth rates without nutrient amendment; $\mu_{\mathrm{n}}$, phytoplankton growth rates with nutrient amendment; $m$, microzooplankton grazing rates; SST, surface seawater temperature; SSS, surface seawater salinity; Si, silicate; Chl $a$, chlorophyll $a$.

\begin{tabular}{|c|c|c|c|c|c|c|c|c|c|}
\hline & $\mu$ & $m$ & SST & SSS & $\mathrm{Si}$ & Chl $a$ & $m / \mu$ & $\mu / \mu_{\mathrm{n}}$ & $\mu-m$ \\
\hline$\mu$ & 1 & $0.762^{* *}$ & $0.425^{*}$ & $0.547^{* *}$ & -0.348 & $-0.646^{* *}$ & -0.356 & $0.496^{*}$ & $0.827^{* *}$ \\
\hline $\mathrm{m}$ & & 1 & $0.617^{* *}$ & $0.477^{*}$ & -0.206 & $-0.660^{* *}$ & 0.252 & 0.163 & 0.266 \\
\hline SST & & & 1 & 0.225 & -0.289 & $-0.542^{* *}$ & 0.093 & 0.332 & 0.098 \\
\hline SSS & & & & 1 & $-0.465^{*}$ & $-0.519^{*}$ & -0.061 & 0.293 & 0.396 \\
\hline $\mathrm{Si}$ & & & & & 1 & 0.304 & 0.239 & -0.406 & -0.336 \\
\hline Chl $a$ & & & & & & 1 & -0.007 & -0.404 & -0.389 \\
\hline$m / \mu$ & & & & & & & 1 & $-0.597^{* *}$ & $-0.748^{* *}$ \\
\hline$\mu / \mu_{\mathrm{n}}$ & & & & & & & & 1 & $0.596^{* *}$ \\
\hline$\mu-m$ & & & & & & & & & 1 \\
\hline
\end{tabular}

** Significant correlation at the level of 0.01 ; ${ }^{*}$ significant correlation at the level of 0.05 .

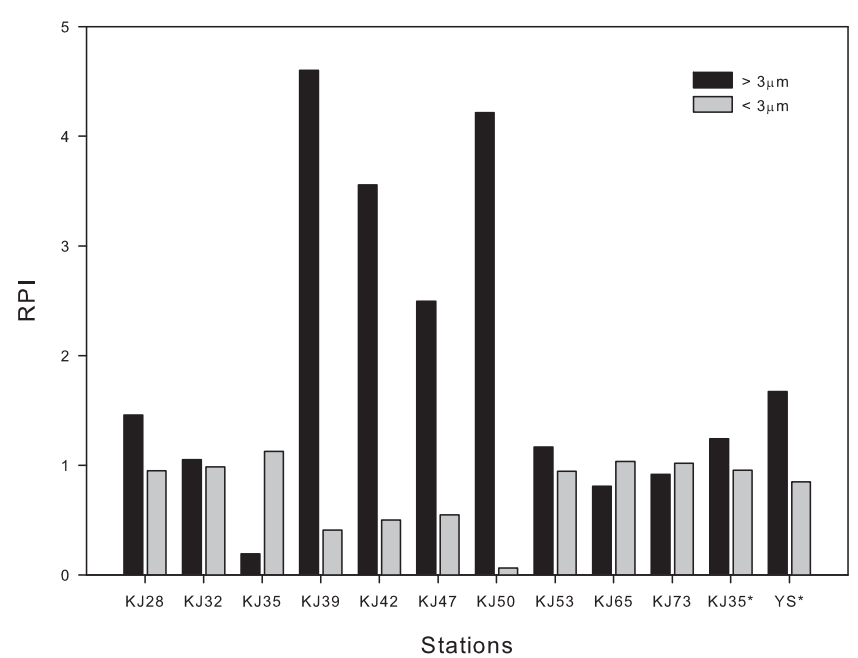

Figure 4. Relative preference index (RPI) for size-fractionated phytoplankton. $>3 \mu \mathrm{m}$, size fraction larger than $3 \mu \mathrm{m} ;<3 \mu \mathrm{m}$, size fraction smaller than $3 \mu \mathrm{m}$; the asterisk indicates experiments conducted in May 2009, others were conducted in November 2010. RPI $>1$ indicates positive selection and vice versa.

\section{Discussion}

\subsection{Comparisons with other studies}

All the $\mu$ (except those obtained at KJ53 during the winter cruise) and $m$ were within the reviewed ranges based on global data collection (Calbet and Landry, 2004; Schmoker et al., 2013). Substantive $m$ but negative $\mu$ were observed at KJ53 (Fig. 3d-f), the only station located on the continental shelf with a bottom depth less than $200 \mathrm{~m}$ (Fig. 1).

\subsubsection{Negative phytoplankton growth rates}

Negative $\mu$ have been extensively reported in previous dilution experiments (e.g. Burkill et al., 1987; Loebl and
Beusekon, 2008; Suzuki et al., 2002; Zhou et al., 2011). Zhou et al. (2013) reviewed that temperature and light regime during incubation, insufficient sampling, contamination of particle-free water and the added nutrients, and decay of phytoplankton blooms could be the possible reasons for the negative $\mu$ in dilution experiments. Our measures to mimic the in situ light and temperature during incubation exclude light and temperature from the factors for the substantially negative $\mu$. Insufficient sampling also unlikely contributed to the negative $\mu$ since sufficient mixing was conducted before $\mathrm{Chl} a$ sampling. The substantive $m$ could exclude contamination as the reason for the negative rates, because contamination could not only cause phytoplankton death, but also less microzooplankton grazing. We conjecture that phytoplankton community decay may occur and lead to the negative $\mu$ at KJ53. The lowest silicate concentration at KJ53 may be related to the phytoplankton community decay and the negative $\mu$. Why the lowest silicate concentration occurred and to what extent the low nutrient condition was related to the negative phytoplankton growth is a topic that needs further assessment.

\subsubsection{Non-linear feeding responses}

Non-linear feeding responses including both the saturated and saturated-increased types occurred in our dilution experiments. Non-linear responses were usually observed in eutrophic waters with high prey abundance (Elser and Frees, 1995; Gallegos, 1989; Teixeira and Figueiras, 2009). Nonlinear feeding responses in dilution experiments conducted in the oligotrophic subtropical Northeast Atlantic in summer have also been reported by Quevedo and Anadón (2001) and Cáceres et al. (2013). However, the authors did not explain the underlying reasons for these phenomena. The oligotrophic conditions and low phytoplankton biomass in their study area were similar to those in the oligotrophic tropical waters of the SSCS. Teixeira and Figueiras (2009) proposed that changes in the specific phytoplankton growth rate 

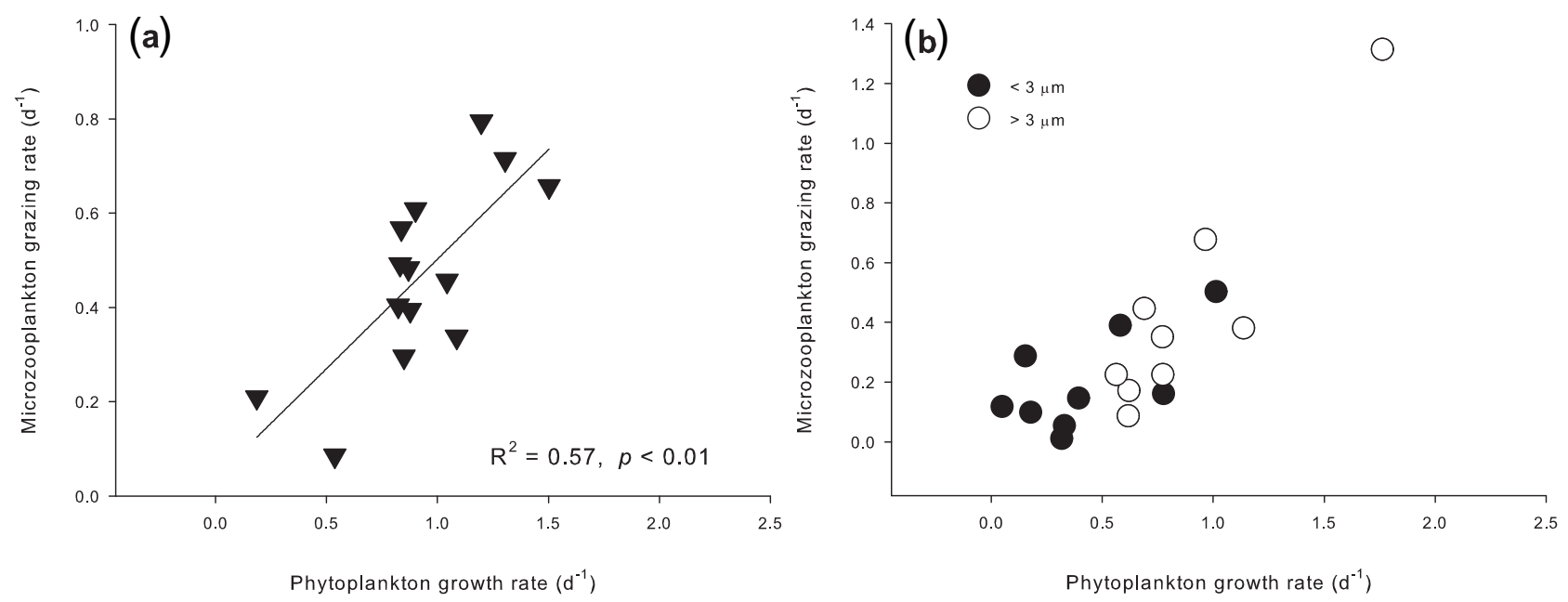

Figure 5. Correlationship between phytoplankton growth and microzooplankton grazing rates. (a) May to June 2009; (b) November 2010; $>3 \mu \mathrm{m}$, size fraction larger than $3 \mu \mathrm{m} ;<3 \mu \mathrm{m}$, size fraction smaller than $3 \mu \mathrm{m}$.

Table 5. Comparisons of environmental variables, and phytoplankton growth and microzooplankton grazing between May-June 2009 and November 2010 in the southern South China Sea. SST, surface seawater temperature $\left({ }^{\circ} \mathrm{C}\right)$; SSS, surface seawater salinity; Si, silicate $(\mu \mathrm{mol} \mathrm{L}-1) ; \mathrm{Chl} a$, chlorophyll $a\left(\mu \mathrm{g} \mathrm{L}^{-1}\right) ; \mu_{\mathrm{n}}$, phytoplankton growth rates with nutrient amendment $\left(\mathrm{d}^{-1}\right) ; \mu$, phytoplankton growth rates without nutrient amendment $\left(\mathrm{d}^{-1}\right) ; m$, microzooplankton grazing rates $\left(\mathrm{d}^{-1}\right) ; p$, the significant level. The mean ratio values of $\mu / \mu_{\mathrm{n}}$ and $m / \mu$ were compared based on the Mann-Whitney test, while the other mean values were compared based on the independent $t$ test. The ratio values of $\mu / \mu_{\mathrm{n}}$ and $m / \mu$ were shown as geometric mean \pm standard deviation, while other parameters were displayed as arithmetic mean \pm standard deviation.

\begin{tabular}{|c|c|c|c|c|c|c|c|c|}
\hline Season & SST & SSS & $\mathrm{Si}$ & Chl $a$ & $\mu / \mu_{\mathrm{n}}$ & $m$ & $\mu$ & $m / \mu$ \\
\hline Summer & $29.64 \pm 0.60$ & $32.82 \pm 0.16$ & $3.8 \pm 2.6$ & $0.066 \pm 0.022$ & $0.80 \pm 0.25$ & $0.46 \pm 0.20$ & $0.92 \pm 0.32$ & $0.49 \pm 0.23$ \\
\hline Winter & $29.27 \pm 0.25$ & $31.92 \pm 0.30$ & $7.9 \pm 4.7$ & $0.104 \pm 0.024$ & $0.54 \pm 0.30$ & $0.27 \pm 0.13$ & $0.54 \pm 0.22$ & $0.48 \pm 0.33$ \\
\hline$p$ & 0.055 & $<0.01$ & $<0.05$ & $<0.01$ & $<0.05$ & $<0.01$ & $<0.01$ & $>0.1$ \\
\hline
\end{tabular}

due to varied nutrient limitation in experimental bottles, in the morality rate related to microzooplankton abundance and feeding behaviour and even virus infection could be related to the non-linear responses. As additional nutrients were added in the experiments bottles, we do not think that nutrient limitation was the factor causing the non-linear responses in our experiments. Instead, we think that the sufficient nutrients added in the experimental bottles led to high phytoplankton abundance in the less-diluted bottles. Microzooplankton may reach a maximum ingestion rate at high food concentration, and the maximum ingestion rate may remain constant despite further increase in prey abundance, which is often used to explain the occurrence of saturated feeding responses in dilution experiments for eutrophic ecosystems (Gallegos, 1989; Moigis, 2006; Teixeira and Figueiras, 2009), and could explain those in our experiments. While the saturated-increased responses observed in the present study imply that decrease in the ingestion rate should occurr along with the further increase in food abundance. There is no concluded explanation for the decrease in the ingestion rate. Teixeira and Figueira (2009) proposed that prey selection by microzooplankton in waters with high and diverse food abundance may account for the decrease. We consider that nutrient amendment in the experimental bottles may give rise to relatively higher phytoplankton (food) abundance, leading to decrease in the ingestion rate and accounting for the occurrence of saturated-increased responses in our experiments.

\subsubsection{Phytoplankton growth and microzooplankton grazing rates in low-latitude tropical waters}

There is no study on microzooplankton grazing in the SSCS, especially in waters around the Nansha Islands. If any, Chen et al. (2009b) reported an average $\mu$ of $0.75 \pm 0.62 \mathrm{~d}^{-1}$ and an average $m$ of $0.65 \pm 0.51 \mathrm{~d}^{-1}$ in the western SCS northwest to the present study waters in summer. These rates were similar to our results observed during the summer cruise (Table 5).

There are few studies on microzooplankton grazing in low-latitude tropical waters such as the SSCS. Landry et al. (1995) reported an average $\mu$ of $0.83 \pm 0.42$ and $m$ of $0.72 \pm 0.56 \mathrm{~d}^{-1}$ in February-March, and an average $\mu$ of $0.98 \pm 0.31$ and $m$ of $0.57 \pm 0.17 \mathrm{~d}^{-1}$ in August-September 
in the central equatorial Pacific Ocean. These results are similar to ours observed during the summer cruise. Landry et al. (2011) reported a low average $\mu$ of $0.43 \pm 0.14$ and $m$ of $0.31 \pm 0.11 \mathrm{~d}^{-1}$ in the high-nutrient-low-chlorophyll (HNLC) equatorial Pacific Ocean. These rates are similar to the rates observed during the winter cruise in the present study. Yang et al. (2004) investigated the phytoplankton growth and microzooplankton grazing in the western Pacific waters with latitudes similar to those of the SSCS. Their reported $\mu$ and $m$ in summer were 0.35 to $0.75 \mathrm{~d}^{-1}$, and 0.51 to $0.67 \mathrm{~d}^{-1}$, which are similar to our results observed during the summer cruise. Landry et al. (1998) showed an average $\mu$ of 0.5 and an average $m$ of $0.6 \mathrm{~d}^{-1}$ at the oligotrophic stations in the subtropical and tropical Arabian Sea. Caron and Denett (1999) reported the $m$ of $0.35 \pm 0.18$ and $0.30 \pm 0.17 \mathrm{~d}^{-1}$ during the northeast monsoon season and spring intermonsoon season in the Arabian Sea, respectively. The $m$ were similar to the low $m\left(0.27 \pm 0.13 \mathrm{~d}^{-1}\right)$ observed during the northeast monsoon season in the present study.

The growth and grazing rates of pico-phytoplankton estimated in the present study fall into the middle range of those rates of the main pico-phytoplankton groups (Prochlorococcus, Synechococcus and eukaryotic pico-phytoplankton) reported in previous studies (reviewed data in Table II in Hirose et al., 2008). Based on cell cycle analysis, Yang and Jiao (2002) reported the in situ Prochlorococcus growth rate of $0.54 \mathrm{~d}^{-1}$ at the chlorophyll maximum layer in the SSCS in May. This rate is lower than the pico-phytoplankton growth rate observed (at YS and KJ35) during the summer cruise, but slightly higher than that $\left(0.42 \mathrm{~d}^{-1}\right.$ on average $)$ observed during the winter cruise. Lower average growth rate $\left(0.15 \mathrm{~d}^{-1}\right)$ of Prochlorococcus in the subtropical and tropical Atlantic has been reported by Zubkov et al. (2000).

\subsection{Seasonal variations in phytoplankton growth and microzooplankton grazing}

Our results showed pronounced seasonal changes in the phytoplankton growth and microzooplankton grazing, but not the microzooplankton grazing impact on phytoplankton $(m / \mu)$, in the SSCS. Many studies have found pronounced seasonality in the phytoplankton growth and microzooplankton grazing in temperate and high-latitude waters (e.g. Calbet et al., 2008; Kim et al., 2007; Lawrence and Menden-Deuer, 2012; Loebl and Beusekon, 2008). Nevertheless, there are few studies on the seasonality of the microzooplankton grazing in oligotrophic tropical waters. From the perspective of phytoplankton growth, Landry et al. (2011) reported that $\mu$ was slightly higher in December than September in the HNLC waters of the equatorial Pacific, but the rate was not significantly different between periods of the southwest monsoon and the early northeast monsoon in the Arabian Sea (Landry et al., 1998); while Caron and Denett (1999) demonstrated that $\mu$ was approximately twice as high during the northeast monsoon season than the spring intermonsoon period in the Arabian Sea. Chen et al. (2013) observed that $\mu$ in surface water of the northern SCS was significantly higher in the summer than winter. However, the previous studies showed no seasonal variation in microzooplankton grazing in the HNLC waters of the equatorial Pacific (Landry et al., 1995, 2011), the Arabian Sea (Caron and Dennett, 1999; Landry et al., 1998) and oligotrophic surface waters of the northern SCS (Chen et al., 2013). Significantly lower $m$ in the summer than winter at the chlorophyll maximum layer in the northern SCS has been reported by Chen et al. (2013). From the data published by Quevedo and Anadón (2001), we calculated that the $\mu$ and $m$ were higher in the summer $\left(0.61 \pm 0.43\right.$ and $\left.0.49 \pm 0.28 \mathrm{~d}^{-1}\right)$ than in the spring $\left(0.33 \pm 0.27\right.$ and $\left.0.29 \pm 0.18 \mathrm{~d}^{-1}\right)$ in the oligotrophic subtropical Northeast Atlantic. Lower average $\mu$ and $m$ for picophytoplankton in the winter than summer have been recently reported in the subtropical East China Sea (Guo et al., 2014). These results are consistent with the significant seasonal variations in the phytoplankton growth and microzooplankton grazing in the SSCS in the present study.

\subsection{East Asian monsoon influencing seasonal variations in phytoplankton growth and microzooplankton grazing by affecting nutrient supply and salinity decrease in surface water}

Seasonal variations in environmental variables, related to the East Asian monsoon, may directly and/or indirectly influence phytoplankton growth and microzooplankton grazing. Significant seasonal changes in a host of environmental variables including salinity, dissolved inorganic nutrients, and phytoplankton biomass were indeed observed (Table 5). The correlationship between $\mu$ and $m$ with the environmental variables indicate that seasonal variations in the phytoplankton growth and microzooplankton grazing were related to the contrasting environmental conditions under the influence of the East Asian monsoon (Table 4).

Many studies have showed increased $m$ during the warmest seasons and reduced $m$ and $\mu$ in winter months (e.g. Ara and Hiromi, 2009; Lawrence and Menden-Deuer, 2012). Both the $\mu$ and $m$ were positively correlated with temperature in the present study. However, the mean seasonal temperature discrepancy was less than $0.4^{\circ} \mathrm{C}$ and not significant (independent $t$ test, $p=0.055$ ) (Table 5). We do not think this slight temperature variation alone could account for the substantial decrease in the $\mu$ and $m$ observed in the northeast monsoon season.

We think that changes in dissolved inorganic nutrients and other factors associated with SSS may be the main drivers for the variations in the phytoplankton growth and microzooplankton grazing observed in the present study. The significantly higher concentration of dissolved inorganic nutrients such as silicate could support the nearly twice as high $\mathrm{Chl} a$ concentration during the northeast monsoon season than the summer. The higher concentrations of silicate and Chl $a$ are 
consistent with previous results of relatively higher dissolved nutrients, phytoplankton biomass and primary production in surface waters of the SCS in winter (Liu et al., 2002; Ning et al., 2004). It is easy to understand that the stronger northeast monsoon could increase nutrient supply to the surface layer by enhancing vertical mixing and basin-scale uplift of nutricline depth (Liu et al., 2002). However, this kind of nutrient supply in the SSCS could be episodically influenced by intermittent arrivals of the strong northeast monsoon in the form of strong cold air. Therefore, we infer that nutrient supply to the surface water under the influence of the northeast monsoon may stimulate sporadic enhancement in phytoplankton production and biomass.

The arrival of strong northeast monsoon may bring not only nutrient supply to the surface water as a result of enhanced vertical mixing, but also SSS decrease due to heavy frontal rainfall when the cold air meets the warm and wet local air. A strong rainy season is usually developed from October to January in the SSCS (Wyrtki, 1961). The remotesensing data from the Tropical Rainfall Measuring Mission indeed showed that apparently larger rainfall occurred during the winter than summer (Fig. 6). The large rainfall could not only bring nutrients such as nitrate in rainwater to the surface water (Kodama et al., 2011), but also dilute and freshen the surface seawater (as those observed during the winter cruise). In addition, after the passage of the strong cold air, the winds over the SSCS are always weak. The low-wind condition could facilitate the less saline surface water overlying on the more saline deep water to form the "freshwater cap" (Zeng et al., 2009). The salinity discrepancy between surface water and that at $25 \mathrm{~m}$ in depth was several times higher during the winter cruise (0.99) than the summer cruise (0.17) (Tables 1 and 2), indicating that a freshwater cap formed during the winter cruise in the SSCS (Fig. 2).

The freshwater cap could enhance water stratification and block nutrient supply to the surface layer, thus nutrients in surface water could be depleted by the phytoplankton community, and lead to nutrient limitation to the growth of the phytoplankton community with already increased biomass. The high $\mu / \mu_{\mathrm{n}}$ (approximate to or higher than one) indicated that phytoplankton growth was only slightly or even not nutrient-limited during the summer cruise (Table 1). Similar results in the oligotrophic subtropical Northeast Atlantic have also been reported (Cáceres et al., 2013; Quevedo and Anadón, 2001). In contrast, severe nutrient limitation indicated by the lower $\mu / \mu_{\mathrm{n}}(0.54 \pm 0.30)$ was observed during the winter, which may account for part of the low $\mu$ (Table 5).

The freshwater cap could also impact the microzooplankton grazing indirectly. First, the formation of freshwater cap might inhibit the migration of mesozooplankton (e.g. copepods) into the water with lower salinity and change the mesozooplankton composition in the water column in the studied waters, as similar salinity effects on mesozooplankton have been observed in estuarine and inshore waters (Grindley, 1964; Zhou et al., 2015b), which can release the
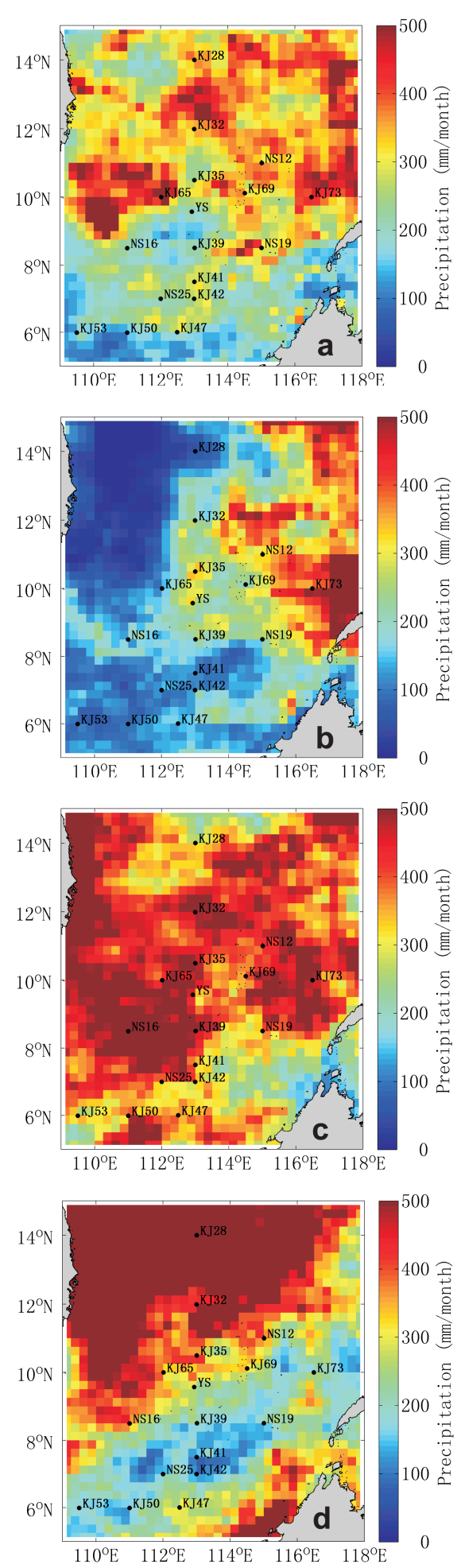

Figure 6. Monthly rainfall in the southern South China Sea estimated on the basis of data from the Tropical Rainfall Measuring Mission. (a) May 2009; (b) June 2009; (c) October 2010; (d) November 2010. 
mesozooplankton grazing pressure on ciliates, then through trophic cascades increase the ciliate grazing on nanoflagellates (HNF) (Chen et al., 2012), reducing the abundance of HNF - the main grazer on pico-phytoplankton (Safi and Hall, 1999) - and releasing the grazing pressure on picophytoplankton (Klauschies et al., 2012). Second, as discussed above, the impeding effect of freshwater cap on phytoplankton accesses to nutrients could lead to poor food quality of phytoplankton as prey, and thus reduce the grazing activity of microzooplankton. Both the arguments suggest that the SSS decrease could result in low microzooplankton grazing rate on pico-phytoplankton such as that observed in the winter cruise.

\subsection{Decoupling between phytoplankton growth and microzooplankton grazing influenced by the winter monsoon}

The different correlationship between $\mu$ and $m$ suggested that coupling between phytoplankton and microzooplankton also varied between the two seasons. Close coupling between phytoplankton growth and microzooplankton grazing indicated by the positive correlation between $\mu$ and $m$ were broadly reported in previous studies (discussion in Zhou et al., 2011). Our results also showed that the microzooplankton grazing was closely coupled with the phytoplankton growth in the summer cruise, but was not in the winter cruise. Previous studies suggested that the lower nutrient concentration and phytoplankton biomass may facilitate the higher coupling between phytoplankton growth and microzooplankton grazing in summer than in winter (Cáceres et al., 2013; Schmoker et al., 2013). We consider that the influence of the northeast monsoon could break the coupling between phytoplankton growth and microzooplankton grazing in winter. Firstly, the arrival of strong northeast monsoon supplies nutrients from deep water to the surface by enhancing vertical mixing. This episodic input of nutrients could break the coupling between phytoplankton and microzooplankton by stimulating $\mu$ and overwhelming the corresponding $m$ and/or changing the phytoplankton community composition (Irigoien et al., 2005). Secondly, large rainfall and the resulted SSS decrease may decouple the phytoplankton (especially the pico-phytoplankton) growth and microzooplankton grazing through indirectly influencing the phytoplankton growth and microzooplankton grazing as discussed in Sect. 4.3.

Why the coupling between phytoplankton growth and microzooplankton grazing was still significant for the larger size fraction but not for the pico-phytoplankton in winter is still open to discussion. On the basis of the size-fractionated data from two sites (YS and KJ35) in summer, it is found that both the growth and grazing rates for the larger size fraction were comparable between the two seasons, while the growth rates of pico-phytoplankton were apparently lower in winter than in summer. We conjecture that the significant environmental change (such as salinity decrease) in winter may do harm to the growth of pico-phytoplankton dominated by Prochlorococcus in the SSCS (Wang et al., 2016), and as a result, the inhibited pico-phytoplankton growth could contribute to the decoupling between the pico-phytoplankton growth and microzooplankton grazing. To confirm this, further studies on the effects of environmental variables on picophytoplankton growth are apparently necessary.

\subsection{Implications of the low microzooplankton grazing impact on phytoplankton}

As discussed in Sect. 4.1.3, our data of the $\mu$ and $m$ were similar to most of the previous results observed in low-latitude tropical waters, but the $m / \mu$ in the SSCS was relatively lower $(<50 \%$ on average) than those reported in the previous studies except that a similar value $(49 \%)$ in the Arabian Sea during the northeast monsoon season has been reported by Caron and Denett (1999). Our $m / \mu$ is also lower than the mean values in most of the global sea regions (Schmoker et al., 2013). The low $m / \mu$, i.e. the high growth differential over grazing indicates low remineralization of organic matter mediated by microzooplankton and mismatch between the primary production and microzooplankton grazing. As a result, potentially high vertical biogenic particle fluxes via the formation of phytoplankton aggregates and consumption of those aggregates by mesozooplankton could occur (Legendre and Rassoulzadegan, 1996; Schmoker et al., 2013). Higher vertical biogenic particle fluxes in the prevailing periods of the monsoons than between the monsoons in the SSCS was indeed observed (Wan et al., 2010). Our results suggest that the high growth differential over microzooplankton grazing may account for part of the high vertical biogenic particle fluxes in the SSCS.

\subsection{Size-selective grazing contributes to the pico-phytoplankton dominance in the oligotrophic waters of the SSCS}

Size selectivity of microzooplankton grazing have been proposed in previous studies (e.g., Burkill et al., 1987; Froneman and Perissinotto, 1996; Huang et al., 2011; Kuipers and Witte, 1999; Sun et al., 2004), and varied patterns of the size selectivity have been reported. For example, higher grazing rate on smaller phytoplankton has been reported accounting for the larger-sized phytoplankton dominance in eutrophic waters (e.g. Strom et al., 2007), but no such pattern was found in other studies (Lie and Wong, 2010; Safi et al., 2007; Strom and Fredrickson, 2008; Zhou et al., 2011). In contrast, Zhou et al. (2015a) found that microzooplankton selectively grazed on nano-phytoplankton $(3-20 \mu \mathrm{m})$ in the oligotrophic waters of the SCS in summer, and proposed that the size-selective grazing on nano-phytoplankton contributes to the pico-phytoplankton dominance there. Higher microzooplankton grazing rate on the large-sized phytoplankton 
( $>5 \mu \mathrm{m})$ than the smaller one $(<5 \mu \mathrm{m})$ has also been recently reported in the oligotrophic subtropical Northeast Atlantic (Cáceres et al., 2013).

The higher RPI (Fig. 4) and higher $m$ (Tables 1 and 2) on the larger-sized phytoplankton than pico-phytoplankton suggests that microzooplankton selectively grazed on the larger-sized phytoplankton in the SSCS both in the summer and winter. The size-selective grazing balanced part of the relative higher growth rate of the larger-sized phytoplankton $(>3 \mu \mathrm{m})$, and led to the nearly equal grazing impact $(m / \mu)$ on both the larger-sized phytoplankton and picophytoplankton in the winter (Table 3). As a result, microzooplankton grazing maintained the pico-phytoplankton dominance in the study waters during the winter. Therefore, on the basis of the results observed in the present study and those reported by Zhou et al. (2015a) and Cáceres et al. (2013), we propose that microzooplankton grazing contributes to the pico-phytoplankton dominance in oligotrophic subtropical and tropical waters such as that of the SCS.

\section{Conclusions}

Significant seasonal variations in $\mu$ and $m$ as well as environmental variables under the influence of the East Asian monsoon were observed in the SSCS. Nutrient supply to the surface influenced by vertical mixing and SSS decrease related to large rainfall were considered as the main factors accounting for the significant low $\mu$ and $m$, and the decoupling between the $\mu$ and $m$ in the SSCS in the winter.

The $m / \mu$ did not significantly vary between the two seasons. The low $m / \mu(<50 \%$ on average), i.e. the high growth differential over microzooplankton grazing indicates low remineralization of organic matter mediated by microzooplankton and mismatch between the $\mu$ and $m$, and may account for part of the high vertical biogenic particle fluxes in the prevailing periods of the monsoons in the SSCS.

Significant size-selective grazing on the larger-sized $(>3 \mu \mathrm{m})$ phytoplankton was observed in the SSCS both in the summer and winter, which indicates that microzooplankton grazing contributes to the pico-phytoplankton dominance in the oligotrophic tropical waters of the SCS.

Author contributions. L. Zhou designed the experiments and carried them out. Y. Tan and L. Huang supervised the projects. Z. Hu provided the monthly rainfall data and the Fig. 6. Z. Ke provided part of the nutrient data. L. Zhou prepared the manuscript with contributions from all authors.

Acknowledgements. We thank the captain and crew of $\mathrm{R} / \mathrm{V}$ Shiyan 3 for their assistance, Shengfu Wang and Shuai Xing for providing part of the nutrient data, and three anonymous reviewers for their helpful comments. This worked was supported by the National Natural Science Foundation of China (Grant
No. 41130855; 41276162), the Strategic Priority Research Program of the Chinese Academy of Sciences (Grant No. XDA05030403; XDA11020203), the Natural Science Foundation of Guangdong Province, China (Grant No. 2015A030310169), the Science and Technology Planning Project of Guangdong Province, China (Grant No. 2014B030301064).

Edited by: K. Suzuki

\section{References}

An-Yi, T., Chin, W.-M., and Chiang, K.-P.: Diel patterns of grazing by pigmented nanoflagellates on Synechococcus spp. in the coastal ecosystem of subtropical western Pacific, Hydrobiologia, 636, 249-256, 2009.

Ara, K. and Hiromi, J.: Seasonal variability in plankton food web structure and trophodynamics in the neritic area of Sagami Bay, Japan, J. Oceanogr., 65, 757-779, 2009.

Banse, K.: Do we live in a largely top-down regulated world?, J. Biosci., 32, 791-796, 2007.

Banse, K.: Reflections about chance in my career, and on the topdown regulated world, Annu. Rev. Mar. Sci., 5, 1-19, 2013.

Burkill, P. H., Mantoura, R. F. C., Llewellyn, C. A., and Owens, N. J. P.: Microzooplankton grazing and selectivity of phytoplankton in coastal waters, Mar. Biol., 93, 581-590, 1987.

Cáceres, C., Taboada, F. G., Höfer, J., and Anadón, R.: Phytoplankton growth and microzooplankton grazing in the subtropical Northeast Atlantic, PLoS ONE, 8, e69159, doi:10.1371/journal.pone.0069159, 2013.

Calbet, A. and Landry, M. R.: Phytoplankton growth, microzooplantkon grazing, and carbon cycling in marine systems, Limnol. Oceanogr., 49, 51-57, 2004.

Calbet, A., Trepat, I., Almeda, R., Salo, V., Saiz, E., Movilla, J. I., Alcaraz, M., Yebra, L., and Simó, R.: Impact of micro-and nanograzers on phytoplankton assessed by standard and sizefractionated dilution grazing experiments, Aquat. Microb. Ecol., 50, 145-156, 2008.

Caron, D. A. and Dennett, M. R.: Phytoplankton growth and mortality during the 1995 Northeast Monsoon and Spring Intermonsoon in the Arabian Sea, Deep-Sea Res. Pt. II, 46, 1665-1690, 1999.

Chen, B., Liu, H., Landry, M. R., Chen, M., Sun, J., Shek, L., Chen, X., and Harrison, P. J.: Estuarine nutrient loading affects phytoplankton growth and microzooplankton grazing at two contrasting sites in Hong Kong coastal waters, Mar. Ecol.-Prog. Ser., 379, 77-90, 2009a.

Chen, B., Liu, H., Landry, M. R., Dai, M., Huang, B., and Sun, J.: Close coupling between phytoplankton growth and microzooplankton grazing in the western South China Sea, Limnol. Oceanogr., 54, 1084-1097, 2009b.

Chen, B., Zheng, L., Huang, B., Song, S., and Liu, H.: Seasonal and spatial comparisons of phytoplankton growth and mortality rates due to microzooplankton grazing in the northern South China Sea, Biogeosciences, 10, 2775-2785, doi:10.5194/bg-10-27752013, 2013.

Chen, J.-Y., Tsai, A.-Y., Gong, G.-C., and Chiang, K.-P.: Grazing pressure by ciliates on the nanoflagellate community in a subtropical pelagic continental shelf ecosystem: small ciliates (of 
$<45 \mu \mathrm{m}$ ) are major consumers of the nanoflagellate community, Zool. Stud., 51, 1308-1318, 2012.

Chen, Q. and Mutidisciplinary Expedition to Nansha Islands, C. A. o. S.: Research Reports on the Nansha Islands and its Adjacent Waters, Beijing, China, 820 pp., 1989.

Chen, Q. and Mutidisciplinary Expedition to Nansha Islands, C. A. o. S. (Eds.): Proceedings of Studies on Marine Organisms in Nansha Islands and Adjacent Waters I, Ocean Press, Beijing, China, 1991.

Chen, Q. and Mutidisciplinary Expedition to Nansha Islands, C. A. o. S. (Eds.): Studies on Marine Fauna and Flora and Biogeography of the Nansha Islands and Neighboring Waters I, Ocean Press, Beijing, China, 1994.

Chen, Q. and Mutidisciplinary Expedition to Nansha Islands, C. A. o. S. (Eds.): Studies on Marine Fauna and Flora and Biogeography of the Nansha Islands and Neighboring Waters II, Ocean Press, Beijing, China, 1996.

Chen, Q. and Mutidisciplinary Expedition to Nansha Islands, C. A. o. S. (Eds.): Studies on Marine Fauna and Flora and Biogeography of the Nansha Islands and Neighboring Waters III, Ocean Press, Beijing, China, 1998.

Christaki, U., Vázquez-Domínguez, E., Courties, C., and Lebaron, P.: Grazing impact of different heterotrophic nanoflagellates on eukaryotic (Ostreococcus tauri ) and prokaryotic picoautotrophs (Prochlorococcus and Synechococcus), Environ. Microbiol., 7, 1200-1210, 2005.

Dolan,, J. R. and McKeon, K.: The reliability of grazing rate estimates from dilution experiments: Have we over-estimated rates of organic carbon consumption by microzooplankton?, Ocean Sci., 1, 1-7, doi:10.5194/os-1-1-2005, 2005.

Elser, J. J. and Frees, D. L.: Microconsumer Grazing and Sources of Limiting Nutrients for Phytoplankton Growth - Application and Complications of a Nutrient-Deletion/Dilution-Gradient Technique, Limnol. Oceanogr., 40, 1-16, 1995.

Fang, W. D., Guo, Z. X., and Huang, Y. T.: Observational study of the circulation in the southern South China Sea, Chinese Sci. Bull., 43, 898-905, 1998.

Fang, W. D., Fang, G., Shi, P., Huang, Q., and Xie, Q.: Seasonal structures of upper layer circulation in the southern South China Sea from in situ observations, J. Geophys. Res., 107, 3202, doi:10.1029/2002JC001343, 2002.

Frias-Lopez, J., Thompson, A., Waldbauer, J., and Chisholm, S. W.: Use of stable isotope-labelled cells to identify active grazers of picocyanobacteria in ocean surface waters, Environ. Microbiol., 11, 512-525, 2009.

Froneman, P. W. and Perissinotto, R.: Structure and grazing of the microzooplankton communities of the Subtropical Covergence and a warm-core edyy in the Altantic sector of the Southern Ocean, Mar. Ecol.-Prog. Ser., 135, 237-245, 1996.

Gallegos, C. L.: Microzooplankton grazing on phytoplankton in the Rhode River, Maryland: nonlinear feeding kinetics, Mar. Ecol.Prog. Ser., 57, 23-33, 1989.

Grindley, J. R.: Effect of low-salinity water on the vertical migration of estuarine plankton, Nature, 203, 781-782, 1964.

Guo, C., Liu, H., Zheng, L., Song, S., Chen, B., and Huang, B.: Seasonal and spatial patterns of picophytoplankton growth, grazing and distribution in the East China Sea, Biogeosciences, 11, 1847-1862, doi:10.5194/bg-11-1847-2014, 2014.
Gutiérrez-Rodríguez, A., Latasa, M., Mourre, B., and Laws, E. A.: Coupling between phytoplankton growth and microzooplankton grazing in dilution experiments: potential artefacts, Mar. Ecol.Prog. Ser., 383, 1-9, 2009.

Hirose, M., Katano, T., and Nakano, S.-I.: Growth and grazing mortality rates of Prochlorococcus, Synechococcus and eukaryotic picophytoplankton in a bay of the Uwa Sea, Japan, J. Plankton Res., 30, 241-250, 2008.

Huang, B., Xiang, W., Zeng, X., Chiang, K.-P., Tian, H., Hu, J., Lan, W., and Hong, H.: Phytoplankton growth and microzooplankton grazing in a subtropical coastal upwelling system in the Taiwan Strait, Cont. Shelf Res., 31, S48-S56, 2011.

Huang, L. and Multidisciplinary Expedition to Nansha Islands, C. A. o. S. (Eds.): A Study on Ecological Processes of Nansha Islands Sea Area I, Science Press, Beijing, China, 1997.

Irigoien, X., Flynn, K. J., and Harris, R. P.: Phytoplankton blooms: a "loophole" in microzooplankton grazing impact?, J. Plank. Res., 27, 313-321, 2005.

Kim, S., Park, M. G., Moon, C., Shin, K., and Chang, M.: Seasonal variations in phytoplankton grwoth and microzooplankton grazing in a temperate coastal embayment, Korea, Estuar. Coast. Shelf Sci., 71, 159-169, 2007.

Klauschies, T., Bauer, B., Aberle-Malzahn, N., Sommer, U., and Gaedke, U.: Climate change effects on phytoplankton depend on cell size and food web structure, Mar. Biol., 159, 2455-2478, 2012.

Kodama, T., Furuya, K., Hashihama, F., Takeda, S., and Kanda, J.: Occurrence of rain-origin nitrate patches at the nutrient-depleted surface in the East China Sea and the Philippine Sea during summer, J. Geophys. Res., 116, C08003, doi:10.1029/2010jc006814, 2011.

Kuipers, B. R. and Witte, H. J.: Grazing impact of microzooplankton on different size classes of algae in the North Sea in early spring and mid-summer, Mar. Ecol.-Prog. Ser., 180, 93-104, 1999.

Landry, M. R. and Calbet, A.: Microzooplankton production in the oceans, ICES J. Mar. Sci., 61, 501-507, 2004.

Landry, M. R. and Hassett, R. P.: Estimating the grazing impact of marine micro-zooplankton, Mar. Biol., 67, 283-288, 1982.

Landry, M. R., Constantinou, J., and Kirshtein, J.: Microzooplankton grazing in the central equatorial Pacific during February and August, 1992, Deep-Sea Res. Pt. II, 42, 657-671, 1995.

Landry, M. R., Brown, S. L., Campbell, L., Constantinou, J., and Liu, H.: Spatial patterns in phytoplankton growth and microzooplankton grazing in the Arabian Sea during monsoon forcing, Deep-Sea Res. Pt. II, 45, 2353-2368, 1998.

Landry, M. R., Selph, K. E., Taylor, A. G., Décima, M., Balch, W. M., and Bidigare, R. R.: Phytoplankton growth, grazing and production balances in the HNLC equatorial Pacific, Deep-Sea Res. Pt. II, 58, 524-535, 2011.

Lawrence, C. and Menden-Deuer, S.: Drivers of protistan grazing pressure: seasonal signals of plankton community composition and environmental conditions, Mar. Ecol.-Prog. Ser., 459, 39-52, 2012.

Legendre, L. and Rassoulzadegan, F.: Food-web mediated export of biogenic carbon in oceans: hydrodynamic control, Mar. Ecol.Prog. Ser., 145, 179-193, 1996.

Lie, A. A. Y. and Wong, C. K.: Selectivity and grazing impact of microzooplankton on phytoplankton in two subtropical semi- 
enclosed bays with different chlorophyll concentrations, J. Exp. Mar. Biol. Ecol., 390, 149-159, 2010.

Liu, K. K., Chao, S. Y., Shaw, P. T., Gong, G. C., Chen, C. C., and Tang, T. Y.: Monsoon-forced chlorophyll distribution and primary production in the South China Sea: observations and a numerical study, Deep-Sea Res. Pt. I, 49, 1387-1412, 2002.

Loebl, M. and Beusekon, J. E. E. V.: Seasonality of microzooplankton grazing in the northern Wadden Sea, J. Sea Res., 59, 203216, 2008.

Longhurst, A. R.: Chapter 11 - The Pacific Ocean, in: Ecological Geography of the Sea (Second Edition), edited by: Longhurst, A. R., Academic Press, Burlington, 2007.

Moigis, A. G.: The clearance rate of microzooplankton as the key element for describing estimated non-linear dilution plots demonstrated by a model, Mar. Biol., 149, 743-762, 2006.

Ning, X., Chai, F., Xue, H., Cai, Y., Liu, C., and Shi, J.: Physicalbiological oceanographic coupling influencing phytoplankton and primary production in the South China Sea, J. Geophys. Res., 109, C10005, doi:10.1029/2004jc002365, 2004.

Obayashi, Y. and Tanoue, E.: Growth and mortality rates of phytoplankton in the northwestern North Pacific estimated by the dilution method and HPLC pigment analysis, J. Exp. Mar. Biol. Ecol., 280, 33-52, 2002.

Parsons, T. R., Maita, Y., and Lalli, C. M.: A Manual of Chemical and Biological Methods for Seawater Analysis, Pergamon Press, Oxford, 1984.

Quevedo, M. and Anadón, R.: Protist control of phytoplankton growth in the subtropical north-east Atlantic, Mar. Ecol.-Prog. Ser., 221, 29-38, 2001.

Safi, K. A. and Hall, J. A.: Mixotrophic and heterotrophic nanoflagellate grazing in the convergence zone east of New Zealand, Aquat. Microb. Ecol., 20, 83-93, 1999.

Safi, K. A., Brian Griffiths, F., and Hall, J. A.: Microzooplankton composition, biomass and grazing rates along the WOCE SR3 line between Tasmania and Antarctica, Deep-Sea Res. Pt. I, 54, 1025-1041, 2007.

Schmoker, C., Hernández-León, S., and Calbet, A.: Microzooplankton grazing in the oceans: impacts, data variability, knowledge gaps and future directions, J. Plank. Res., 35, 691-706, 2013.

Strom, S. L. and Fredrickson, K. A.: Intense stratification leads to phytoplankton nutrient limitation and reduced microzooplankton grazing in the southeastern Bering Sea, Deep-Sea Res. Pt. II, 55, 1761-1774, 2008.

Strom, S. L., Macri, E. L., and Olson, M. B.: Microzooplankton grazing in the coastal Gulf of Alaska: Variations in top-down control of phytoplankton, Limnol. Oceanogr., 52, 1480-1494, 2007.

$\mathrm{Su}$, J.: Overview of the South China Sea circulation and its influence on the coastal physical oceanography outside the Pearl River Estuary, Cont. Shelf Res., 24, 1745-1760, 2004.

Suzuki, K., Tsuda, A., Kiyosawa, H., Takeda, S., Nishioka, J., Saino, T., Takahashi, M., and Wong, C. S.: Grazing impact of microzooplankton on a diatom bloom in a mesocosm as etimated by pigment-specifc dilution technique, J. Exp. Mar. Biol. Ecol., 271, 99-120, 2002.
Teixeira, I. and Figueiras, F.: Feeding behaviour and non-linear responses in dilution experiments in a coastal upwelling system, Aquat. Microb. Ecol., 55, 53-63, 2009.

Wan, S., Jian, Z., Cheng, X., Qiao, P., and Wang, R.: Seasonal variations in planktonic foraminiferal flux and the chemical properties of their shells in the southern South China Sea, Sci. China Earth Sci., 53, 1176-1187, 2010.

Wang, J., Tan, Y., Huang, L., Ke, Z., and Zhou, L.: Wintertime picophytoplankton distribution and its driving factors along the $113^{\circ} \mathrm{E}$ meridian in the southern South China Sea, Acta Ecol. Sin., 36, doi:10.5846/stxb201408261697, 2016.

Wyrtki, K.: Physical oceanography of the southeast Asian waters, Scripps Institution of Oceanography, La Jolla, California, 1961.

Yang, E., Choi, J., and Hyun, J.-H.: Distribution and structure of heterotrophic protist communities in the northeast equatorial $\mathrm{Pa}$ cific Ocean, Mar. Biol., 146, 1-15, 2004.

Yang, Y.-h. and Jiao, N.-z.: In situ daily growth rate of Prochlorococcus at the chlorophyll maximum layer in the southern South China Sea: an estimation from cell cycle analysis, Chin. J. Oceanol. Limnol., 20, 8-14, 2002.

Zeng, L., Du, Y., Xie, S.-P., and Wang, D.: Barrier layer in the South China Sea during summer 2000, Dynam. Atmos. Oc., 47, 38-54, 2009.

Zhang, Z., Qiao, F., and Guo, J.: Subsurface eddies in the southern South China Sea detected from in-situ observation in October 2011, Deep-Sea Res. Pt. I, 87, 30-34, 2014.

Zhou, L., Tan, Y., Huang, L., Huang, J., Liu, H., and Lian, X.: Phytoplankton growth and microzooplankton grazing in the continental shelf area of northeastern South China Sea after Typhoon Fengshen, Cont. Shelf Res., 31, 1663-1671, 2011.

Zhou, L., Tan, Y., and Huang, L.: Negative phytoplankton growth rates in dilution experiments and the possible causes, J. Trop. Oceanogr., 32, 48-54, 2013.

Zhou, L., Tan, Y., Huang, L., and Li, G.: Does microzooplankton grazing contribute to the pico-phytoplankton dominance in subtropical and tropical oligotrophic waters?, Acta Ecol. Sin., 35, 29-38, 2015a.

Zhou, L., Huang, L., Tan, Y., Lian, X., and Li, K.: Size-based analysis of a zooplankton community under the influence of the Pearl River plume and coastal upwelling in the northeastern South China Sea, Mar. Biol. Res., 11, 168-179, 2015b.

Zubkov, M. V., Sleigh, M. A., and Burkill, P. H.: Assaying picoplankton distribution by flow cytometry of underway samples collected along a meridional transect across the Atlantic Ocean, Aquat. Microb. Ecol., 21, 13-20, 2000. 